\section{Konisering gir økt risiko for prematur fødsel}

Omfattende eksisjon av vev ved cervikal intraepitelial neoplasi dobler risikoen for både for tidlig fødsel og for fødsel lenge før termin.

Flere studier har vist at kirurgisk behandling av cervikal intraepitelial neoplasi er forbundet med økt risiko for prematur fødsel, men det er uklart hvordan omfanget av eksisjon påvirker risikoen. Dette er nylig undersøkt $i$ en pasient-kontroll-studie med mer enn 1300 kvinner som hadde født i uke 20-36, valgt ut fra en kohort på rundt 11500 kvinner med minst én histologisk prøve tatt med kolposkopi (1).

Risikoen for prematur fødsel var ikke større hos kvinner med en tidligere liten eksisjon $(<10 \mathrm{~mm})$ enn hos kvinner med en diagnostisk biopsi (absolutt risiko 7,5\% versus 7,2\%). Kvinner med middels (10-14 mm), stor $(15-19 \mathrm{~mm})$ og veldig stor $(\geq 20 \mathrm{~mm})$ eksisjon hadde høyere risiko, henholdsvis $9,6 \%, 15,3 \%$ og $18,0 \%$, sammenliknet med kvinner med liten eksisjon. Det samme mønsteret ble observert for de 161 kvinnene som hadde født i uke 20-31. Tid mellom fødsel og kolposkopi/behandling syntes ikke å ha betydning for risikoen.

- Det har tatt lang tid å få de medisinske miljøene til å ta innover seg at konisering er en behandlingsmetode som har innflytelse på graviditetsutfallet, sier Susanne Albrechtsen, som er klinikkoverlege ved Kvinneklinikken ved Haukeland universitetssykehus.

- Denne studien har en velegnet design, og den bekrefter at det å fjerne en del av livmorhalsen, såkalt konisering, ved celleforandringer, gir økt risiko for å føde for tidlig. Omkostningene for hver eneste ekstremt for tidlig fødsel er store, både for det enkelte individ og familien. Resultatene taler for å anbefale metoder og teknikker der minst mulig cervikalt vev blir fjernet hos kvinner i fertil alder, sier Albrechtsen.

Trine B. Haugen

Tidsskriftet

\section{Litteratur}

1. Castanon A, Landy R, Brocklehurst P et al. Risk of preterm delivery with increasing depth of excision for cervical intraepithelial neoplasia in England: nested ase-control study. BMJ 2014; 349: g6223

\title{
Denguefeber og chikungunya i Tanzania
}

\author{
Virusinfeksjoner som denguefeber og chikungunya er en ikke uvanlig \\ årsak til feber hos barn. Det viser en ny studie fra Tanzania. Manglende \\ tilgang på diagnostiske tester gjør at disse tilstandene nok har vært \\ underdiagnostisert.
}

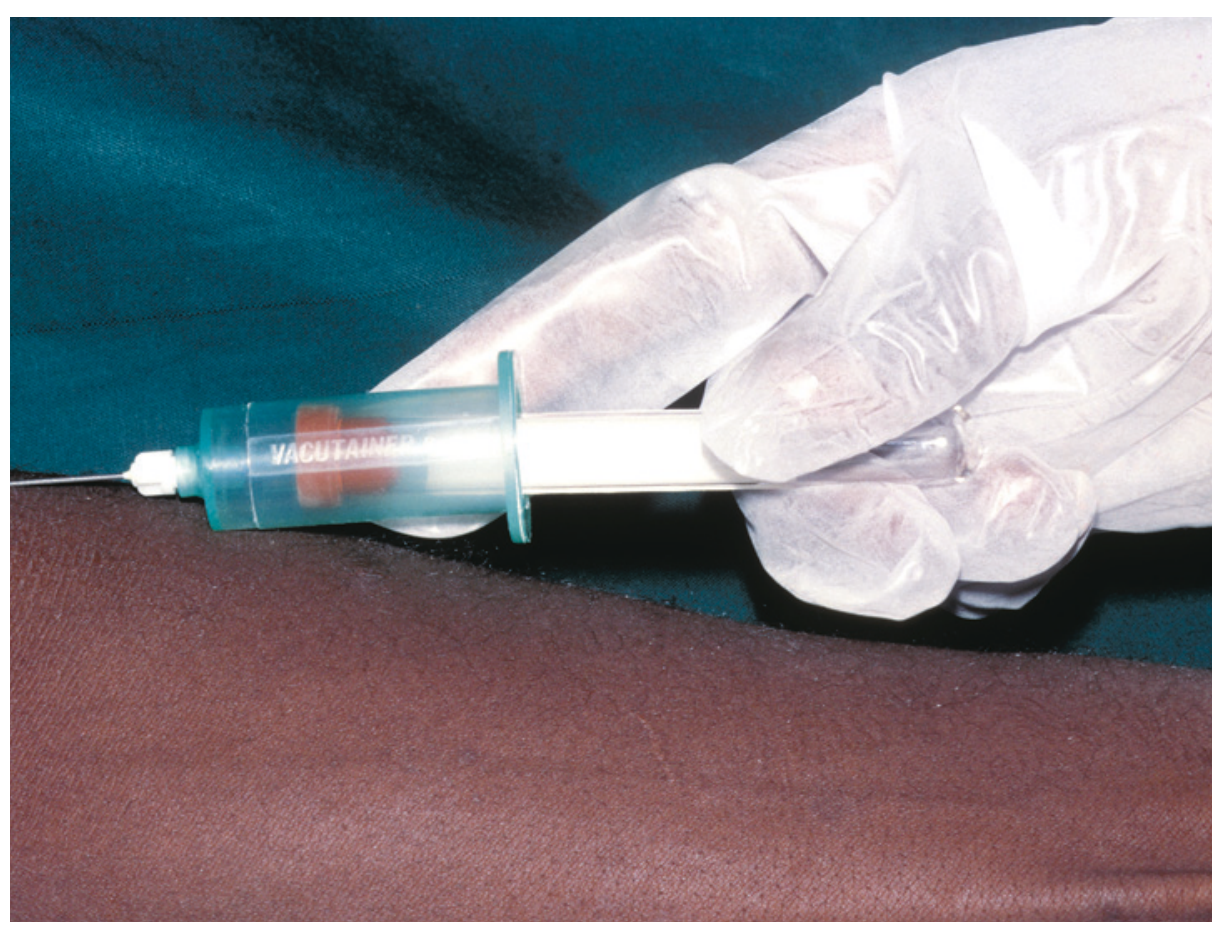

Illustrasjonsfoto: Science Photo Library

Feber er blant de vanligste grunnene til å søke helsehjelp. Mangel på diagnostiske hjelpemidler kan føre til at feber blir oppfattet og behandlet som malaria. En fersk studie fra Tanzania viste imidlertid at det var et bredt spektrum av årsaker til akutt feber (1). Av de 364 pasientene var det 83 (22,8\%) som hadde malaria, men også 76 (20,9\%) med sannsynlig denguefeber, hvorav 29 fikk diagnosen bekreftet. Chikungunya var sannsynlig diagnose hos 17 pasienter $(4,7 \%)$, og det ble også funnet tilfeller av influensavirus-, rotavirus- og adenovirusinfeksjon.

Studien ble gjennomført i to perioder (regntid og tørr periode) i 2013. Man inkluderte poliklinisk behandlede barn (2-13 år) med feber ved et sykehus i Kilosa-distriktet, sentralt i Tanzania. Alle pasientene ble testet for malaria med tykk og tynn dråpe og for chikungunya og dengue med serologisk prøve, der positivt svar tilsa sannsynlig diagnose. I tillegg ble det gjort PCR-test på dengue (plasmal og influensa (nesesekret fra 97 pasienter), og positivt svar på disse ble karakterisert som bekreftet diagnose. Avføringsprøver fra 39 av barna ble testet for rota- og adenovirus.

Det var stor grad av overlapping av symptomer på tvers av de forskjellige diagnosene, og det ble ikke funnet symptomer som kunne skille malaria, denguefeber og chikzungunya. Treffsikkerheten på kliniske diagnoser var lav for denguefeber og chikungunya, idet mange tilfeller ble behandlet med antibiotika, f.eks. for antatt urinveisinfeksjon. Forfatterne anbefaler $ø$ kt bruk av diagnostiske tester for virale tilstander for å bedre behandlingen.

\section{Kristoffer Brodwall}

kristoffer.brodwall@gmail.com

Institutt for global helse og samfunnsmedisin Universitetet i Bergen

\section{Litteratur}

1. Chipwaza B, Mugasa JP, Selemani M et al. Dengue and Chikungunya Fever among Viral Diseases in Outpatient Febrile Children in Kilosa District Hospital, Tanzania. PLoS Negl Trop Dis 2014; 8: e3335. 